\section{DESCRIPTIVE METEOROLOGY.}

Descriptive Meteorology. By Prof. Willis L. Moore, Chief of United States Weather Bureau. Pp. xviii +344 . (New York and London: D. Appleton and Company, 1910.) Price 12s. $6 d$. net.

A TEXT-BOOK by the Chief of the great Weather A Bureau of the United States of America will be received with not a little interest, and Prof. Willis Moore, in submitting this treatise, has had before him the definite aim of providing the young men entering the service of the bureau with "a comprehensive introduction to modern meteorology." We think that the author has in most ways successfully realised his aim, though the great prominence given to American methods and the researches of American official meteorologists make the work to some extent unsuitable for adoption as a text-book for students in other countries. The author warmly expresses his obligation for valuable help received from various colleagues - Abbe, Bigelow, Kimball, Henry, Cox, and Humphreys-and the extent of this indebtedness will be appreciated by those familiar with the writings of these specialists in the "Monthly Weather Review" and in various official bulletins of the bureau. We should have been glad, however, if attention had been directed somewhat more fully to the splendid work of A. L. Rotch, for a book such as this should be a source of inspiration to the student, and nothing in American meteorology is more inspiring than a consideration of the history of the Blue Hill Observatory.

To indicate briefly the scope of the work, we may say that the science of meteorology is given the widest possible reference, and that great attention is devoted to the dynamics of the subject. The opening chapters deal very fully with such general questions as the composition of the earch's atmosphere, the physical condition of the sun and its relation to the earth's atmosphere, and radiation waves in their different forms. Passing to a consideration of the vertical and horizontal distribution of temperature, a special chapter is devoted to an interesting study of the so-called "isothermal layer," where perhaps de Bort's term, "stratosphere," might have been adopted. A discussion of atmospheric pressure and circulation follows-where Buys Ballot's name is not mentionedand Bigelow's work is summarised in considerable detail. Chapters on anemometry and the winds of the globe, on clouds, and on precipitation in its various forms, are good, but the international classification of clouds should have been included. Then follows an admirable discussion of weather forecasting, a chapter on meteorological optics, and a final one on climate -somewhat discursive, but excellent in its treatment of the influence of topographical conditions.

Prof. Moore is a master of the art of condensation and the fortunate possessor of a good sense of proportion, and these qualities have enabled him to cover a wide field in a satisfactory manner. The great organisation the work of which he directs touches the practical interests of the people at many points, and he is at his best in discussing the practical problems of weather forecasting, which are illustrated by an excel-

NO. 2 I 42 , VOL. 85$]$ lent series of weather maps. Again, his brief discussions of such questions of perennial popular interest as the influence of forests on rainfall and the supposed influence of the Gulf Stream on the climate of western Europe are excellent. It was perhaps well practically to exclude mathematical formulæ, but we think that here and there the book might have been strengthened by the inclusion of statistics in tabular form. Thus the vital differences between insular and continental climates would have been most forcibly brought home to the student by actual data for actual places aiong some given parallel of latitude across, say, the Eurasian continent.

Each chapter concludes with an excellent biblio graphy, but the attention of American students might have been directed to the research papers issued from the British Meteorological Office during the last few years. And the book properly ends with an index, but a glance at this leaves us puzzled as to what principle was adopted in the inclusion of proper names. Buchan and Rotch are merely mentioned in the book, and their names are not quoted, nor are those of Bigelow and Humphreys, though their work is laid under heavy contribution, whilst those of less wellknown authors are given. In a book published in I9ro a different adverb should have been used in a reference (p. 194) to "Sir William Thomson (now Lord Kelvin)."

The publishers have done their work well and the volume is a handsome one. The numerous illustrations and charts are excellent, though the map representing the normal distribution of rainfall over the United States would have been more readily grasped had it been printed in different shades of colour instead of merely with red isohyets running over a white surface.

\section{THEORIES AND PHYSICS OF THE SUN.}

(1) Les Théories Modernes du Soleil. By J. Bosler, "Encyclopédie Scientifique." Pp. xii +37o+xii. (Paris: Octave Doin et Fils, I910.) Price 5 francs. (2) Vorlesungen über die Physik der Sonne. By Prof. E. Pringsheim. Pp. viii +435 . (Leipzig and Berlin: B. G. Teubner, 19ro.) Price 16 marks.

I $\mathrm{N}$ the first of these two books, dealing with our central luminary, the sun, the author presents his readers with a very well-arranged survey of the more modern views with respect to this important bodv. The author, who is one of the astronomers at the Meudon Observatory, is in a particularly good position to become acquainted with modern solar researches and opinions, and the solar work in progress at that observatory is second to none.

The book bears evidence of the author's command of his subject, and the method of placing the material before his readers which he has adopted is one that is highly commendable and particularly suitable for the valuable series of volumes which form this "Encyclopédie Scientifique."

Commencing with the general theories of the solar constitution, he makes a brief résumé of older views up to 1860 , which include those of Herschel, Kirch- 